\title{
Brazilian cleaner birds: update and brief reappraisal
}

\author{
Ivan Sazima ${ }^{1,3,4}$ \& Cristina Sazima ${ }^{2}$ \\ ${ }^{1}$ Museu de Zoologia, \\ Universidade Estadual de Campinas - UNICAMP, \\ Rua Albert Einstein, s/n, CP 6109, CEP 13083-970 Campinas, SP, Brazil \\ ${ }^{2}$ Departamento de Biologia Animal, \\ Universidade Estadual de Campinas - UNICAMP, \\ CP 6109, CEP 13083-970 Campinas, SP, Brazil,e-mail: csazima@gmail.com \\ ${ }^{3}$ Corresponding author: Ivan Sazima, e-mail: isazima@gmail.com,www.unicamp.br \\ ${ }^{4}$ Retired and associated as voluntary researcher
}

SAZIMA, I. \& SAZIMA, C. Brazilian cleaner birds: update and brief reappraisal. Biota Neotrop. 10(1): http://www.biotaneotropica.org.br/v10n1/en/abstract?short-communication+bn00710012010.

\begin{abstract}
Some bird species feed on external parasites, such as ticks and flies, on the body of mammals (hosts or clients). So called cleaner birds that occur in Brazil were reviewed recently, but gathering of significant new data indicates the need for an update and a brief reappraisal of such association. New records raise the number of known clients for some cleaning birds. The Southern Caracara (Caracara plancus) picks ticks on cattle, and the Black Caracara (Daptrius ater) picks ticks on capybaras. The Wattled Jacana (Jacana jacana) picks ticks, horseflies, arthropods and organic debris on capybaras, and tick-picking on capybaras by the Shiny Cowbird (Molothrus bonariensis) is substantiated by photographs. The Cattle Tyrant (Machetornis rixosa) deftly catches horseflies on capybaras, and these latter clients are recorded posing for the Giant Cowbird (Molothrus oryzivorus), which also pick parasites from the marsh deer. The Cattle Egret (Bubulcus ibis) definitely picks ticks directly on cattle. With the new records, some poorly documented or controversial issues in the literature are here confirmed, a hypothesis is validated, and a suggestion is invalidated.
\end{abstract}

Keywords: cleaning symbiosis, Ardeidae, Falconidae, Jacanidae, Tyrannidae, Icteridae.

SAZIMA, I. \& SAZIMA, C. Aves limpadoras brasileiras: atualização e breve reavaliação. Biota Neotrop. 10(1): http://www.biotaneotropica.org.br/v10n1/pt/abstract?short-communication+bn00710012010.

Resumo: Algumas espécies de aves alimentam-se de parasitas externos, como carrapatos e moscas, sobre o corpo de mamíferos (hospedeiros ou clientes). As assim denominadas aves limpadoras que ocorrem no Brasil foram recentemente revistas, porém o acúmulo de novos e importantes dados indica a necessidade de atualização e breve reavaliação deste tipo de associação. Novos registros elevam o número de clientes conhecidos para algumas espécies de aves limpadoras. O caracará (Caracara plancus) cata carrapatos em gado vacum, e o gavião-de-anta (Daptrius ater) apanha carrapatos em capivaras. A jaçanã (Jacana jacana) apanha carrapatos, mutucas, artrópodes e partículas orgânicas em capivaras, e a retirada de carrapatos em capivaras pelo vira-bosta (Molothrus bonariensis) é aqui evidenciada por fotografias. O suiriri-cavaleiro (Machetornis rixosa) caça destramente mutucas em capivaras, e estes últimos clientes são aqui registrados posando para a iraúna-grande (Molothrus oryzivorus), que também cata parasitas do cervo-do-pantanal. A garça-vaqueira (Bubulcus ibis) de fato apanha carrapatos diretamente no gado. Com os novos registros, alguns assuntos pouco documentados ou controversos na literatura são aqui confirmados, uma hipótese é validada, e uma sugestão é invalidada.

Palavras-chave: simbiose de limpeza, Ardeidae, Falconidae, Jacanidae, Tyrannidae, Icteridae. 


\section{Introduction}

Several bird species worldwide feed on a variety of food types such as ectoparasites, wounded tissue, and body fluids of mammals. This association type is generally regarded as cleaning symbiosis, in which the birds play the role of cleaners and the mammals are their hosts or clients (e.g., Baber \& Morris 1980, Isenhart \& DeSante 1985, Massei \& Genow 1995, Weeks 2000, Sazima 2008). This association remains poorly studied in the continental part of the Neotropics, although tick-removing bird species were recently reviewed for Brazil (Sazima 2007a).

The main purpose of this paper is to present an update and a brief reappraisal of cleaning birds in Brazil, as new and important data accumulated since the last review on the subject (Sazima 2007a). Thus, we 1) report on new mammal clients for four cleaning bird species; 2) confirm or strengthen some controversial records and/or assumptions; and 3) validate a hypothesis and invalidate a suggestion made in the aforementioned review. We comment on the need for additional records of this association, which remains elusive and poorly known for most cleaning bird species. Additionally, we note that the help of amateur ornithologists and professional wildlife photographers in bringing new data to the attention of professional ornithologists and other biologists should always be encouraged.

\section{Material and Methods}

Cleaning associations between birds and mammals were recorded whenever spotted during field trips through the years 2007-2009 in the areas of Campinas $\left(\sim 22^{\circ} 48^{\prime} \mathrm{S}\right.$ and $\left.47^{\circ} 04^{\prime} \mathrm{W}\right)$ and Itatiba $\left(\sim 23^{\circ} 04^{\prime} \mathrm{S}\right.$ and $46^{\circ} 74^{\prime}$ 'W) in São Paulo State, south-eastern Brazil. The cleaner birds were observed with naked eye, through $10 \times 50$ binoculars and a 70-300 telephoto zoom lens mounted on a SLR camera, from a distance of about 2-30 m. "Ad libitum" and "behaviour" sampling rules (Martin \& Bateson 1986), both of which are adequate for opportunistic records and/or rare behaviours, were used throughout our observations, on occasions documented with photographs. These latter were further used to describe and illustrate the behaviour of the birds and the cleaned mammals; voucher copies are on file at the Museu de Zoologia da Universidade Estadual de Campinas (ZUEC). We also briefly interviewed a few amateur ornithologists and professional wildlife photographers, who recorded cleaner birds associated with mammals in nature. No attempt to quantify or compare the relative occurrence of cleaning behaviour of the bird species was made, due both to our haphazardly collected data and the general lack of suitable data for Brazilian cleaner birds (see Tomazzoni et al. 2005, Sazima 2007a, 2008 for examples).

\section{Results and Discussion}

Cattle Egret, Bubulcus ibis (L.). This open country-dwelling ardeid was usually recorded associated with cattle (Bos taurus L.) and less often with horses (Equus caballus L.) in the area of Campinas, south-eastern Brazil. Several records were made throughout the year, from the morning to the afternoon. The birds mostly foraged on the ground near the grazing mammals, capitalising on the insects flushed by the activity of these ungulates. However, from time to time some individuals paused in their pursuit of flushed insects and approached resting or grazing livestock and pulled one to about 10 ticks (Ixodidae) from several body parts, including the face (Figure 1a) and within the ears. Medium-sized to large ticks were picked, mandibulated and swallowed by the birds, which could have their bill tips soiled with blood from the engorged ticks and horseflies (Tabanidae), these latter also caught on the cattle. Tick-picking by the Cattle Egret directly on cattle is a controversial issue in the literature (Gonzales 1995,
Gasset et al. 2000, Bella 2003, Telfair II 2006, Sazima 2007a), but the records presented here leave no doubt that some individuals display this foraging behaviour. Perhaps this is another instance of a behaviour restricted to particular individuals, circumstances and/or areas, similarly to that suggested for another tick-picking bird, the Smooth-billed Ani, Crotophaga ani (L.) (Sazima 2008).
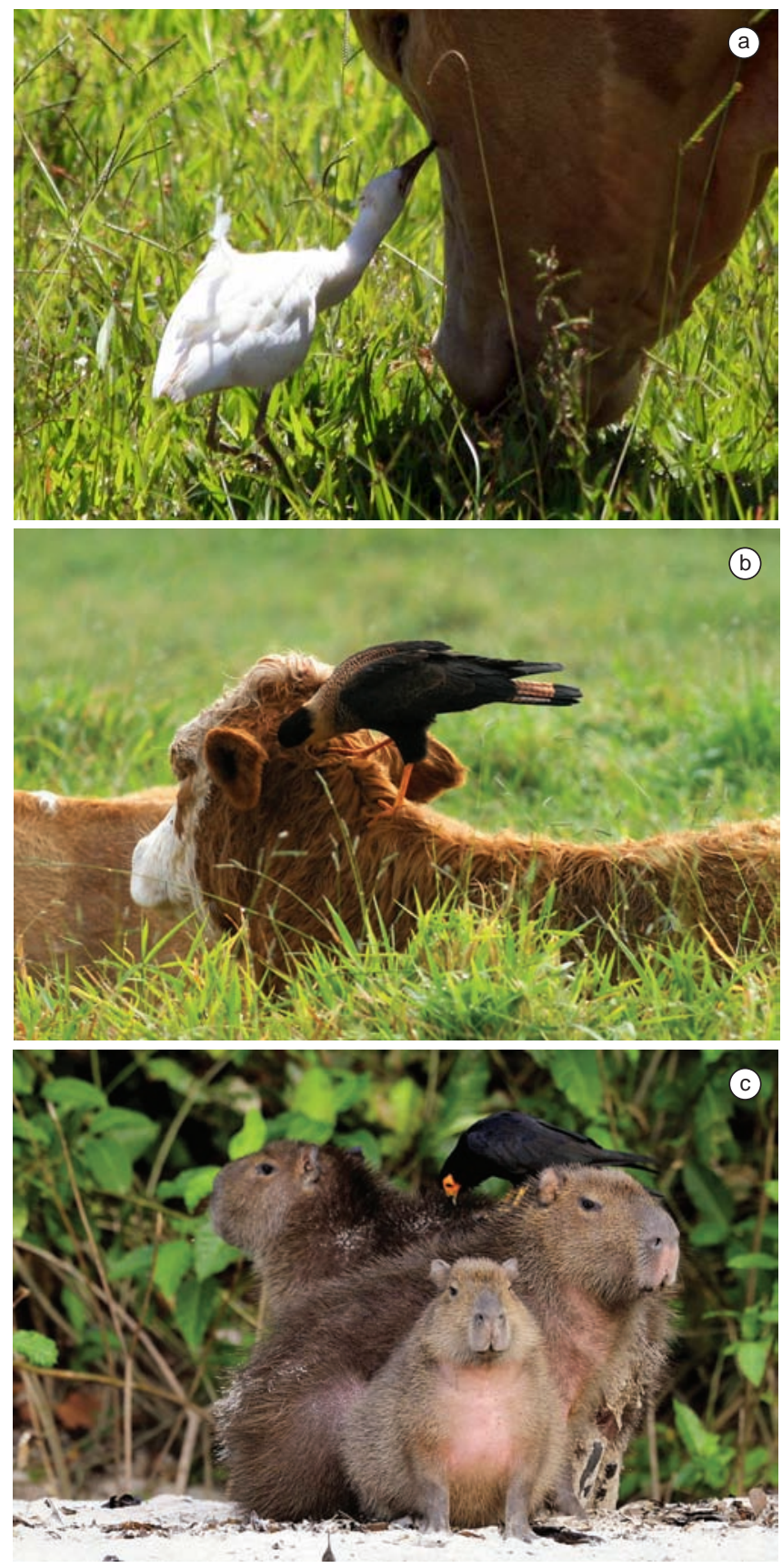

Figure 1. Cleaner birds and their clients: Cattle Egret (Bubulcus ibis) pulls a tick from the face of a grazing ox (a); Southern Caracara (Caracara plancus) picks a tick from the head of a resting heifer (b); Black Caracara (Daptrius ater) inspects the back of a sitting capybara (c). Photo credits: Ivan Sazima (a); Gerson Sobreira (b); Luiz Claudio Marigo (c).

Figura 1. Aves limpadoras e seus clientes: garça-vaqueira (Bubulcus ibis) puxa um carrapato da face de um boi pastando (a), caracará (Caracara plancus) apanha um carrapato na cabeça de uma novilha em descanso (b); gavião-deanta (Daptrius ater) examina o dorso de uma capivara sentada (c). Créditos das fotografias: Ivan Sazima (a); Gerson Sobreira (b); Luiz Claudio Marigo (c). 
Southern Caracara, Caracara plancus (Miller). This open country-dwelling falconid was recorded once associated with capybaras, Hydrochoerus hydrochaeris (L.) in a swamp in the area of Itatiba, south-eastern Brazil, and once with cattle in a pasture in the area of Cambará ( 22 $48^{\prime} \mathrm{S}$ and $\left.47^{\circ} 04^{\prime} \mathrm{W}\right)$, Paraná State, southern Brazil. Both records were made in late austral autumn (May and June, respectively) in the morning. In the first instance, an adult caracara was on the ground and inspected the side and back of a large capybara male that was sitting in the shade. The bird pulled a large tick from the rump of the capybara, which stood and retreated afterwards. The caracara then approached smaller capybaras nearby, which retreated from the bird. The association lasted about 1-2 minutes after first noticed. In the second instance, an adult caracara was perched on a resting heifer and inspected its back and neck. The bird was recorded to pull a few ticks mostly from the hairy neck of the heifer (Figure 1b). The association lasted about 30 seconds when first noticed, to its end when the caracara retreated (G. Sobreira, pers. comm.). The Southern Caracara is recorded to associate with capybaras in Rio Grande do Sul State, southern Brazil (Tomazzoni et al. 2005) and now in south-eastern Brazil (present paper). Cattle are a new client type recorded for this bird.

Black Caracara, Daptrius ater Vieillot. This forest-dwelling falconid was recorded once associated with a group of resting capybaras in a small clearing in the area of the Rio Cristalino, Alta Floresta, Mato Grosso State ( $09^{\circ} 33^{\prime} \mathrm{S}$ and $\left.55^{\circ} 47^{\prime} \mathrm{W}\right)$, south-western Brazil (L. C. Marigo, pers. comm.). The record was made in early austral winter (July) in the morning. There were two caracaras perched on the back of one large capybara, but one of the birds retreated upon the approach of the observer. The perched bird inspected the capybara's back (Figure 1c) and pulled what seemed to be a tick from there during the observation. It remained on the capybara's back for about 10 minutes, after which it also retreated. The Black Caracara is recorded to associate with tapirs, Tapirus terrestris (L.) (Peres 1996) and unspecified deer (Sick 1997). Capybaras are a new client type recorded for this bird.

Wattled Jacana, Jacana jacana (L.). This open country-dwelling jacanid was recorded once associated with capybaras near a swamp in the area of Itatiba, in south-eastern Brazil. The record was made in late austral autumn (May) at midday. An adult jacana was foraging on the ground near three resting capybaras, and approached one of them. The bird inspected the side of the capybara, from where it picked a medium-sized-tick, unidentified arthropods and organic debris, besides deftly catching two horseflies that landed on the client's head. The jacana remained with the capybara for about 1-2 minutes, after which it resumed foraging on the ground. A juvenile bird was recorded associated with capybaras in the area of São Paulo ( $23^{\circ} 32^{\prime} \mathrm{S}$ and $46^{\circ} 38^{\prime}$ W), São Paulo State, south-eastern Brazil in the austral winter (July) at midday (H. Almeida, pers. comm.). The bird was picking arthropods, debris, and probably ticks as well from within the fur of a sitting capybara (Figure 2a). Based on a photograph taken in the Pantanal area, Mato Grosso State, south-western Brazil (Sucksdorff 1985), the Wattled Jacana was hypothesised to act as a cleaner (Sazima 2007a) and the two present records confirm the supposition that capybaras actually are clients. The Northern Jacana, Jacana spinosa (L.) is already recorded as cleaner in Panama, Central America, removing ticks from capybaras (Marcus 1985).

Cattle Tyrant, Machetornis rixosa (Vieillot). This open countrydwelling tyrannid was recorded associated with capybaras on a lake bank in the area of Campinas, south-eastern Brazil. Several records were made throughout the year, most of them in the afternoon. These birds mostly foraged on the ground near grazing capybaras, capitalising on the insects flushed by the activity of these large rodents. From time to time, however, a bird perched on the back (Figure 3a) and even on the head of a capybara and watched for horseflies that landed near the eyes or ears of the rodent. Several times it was recorded deftly catching these blood-taking flies, besides occasionally sallying for other flies and insects from its perch on the capybara. The Cattle Tyrant is recorded to pick ticks on capybaras very occasion-
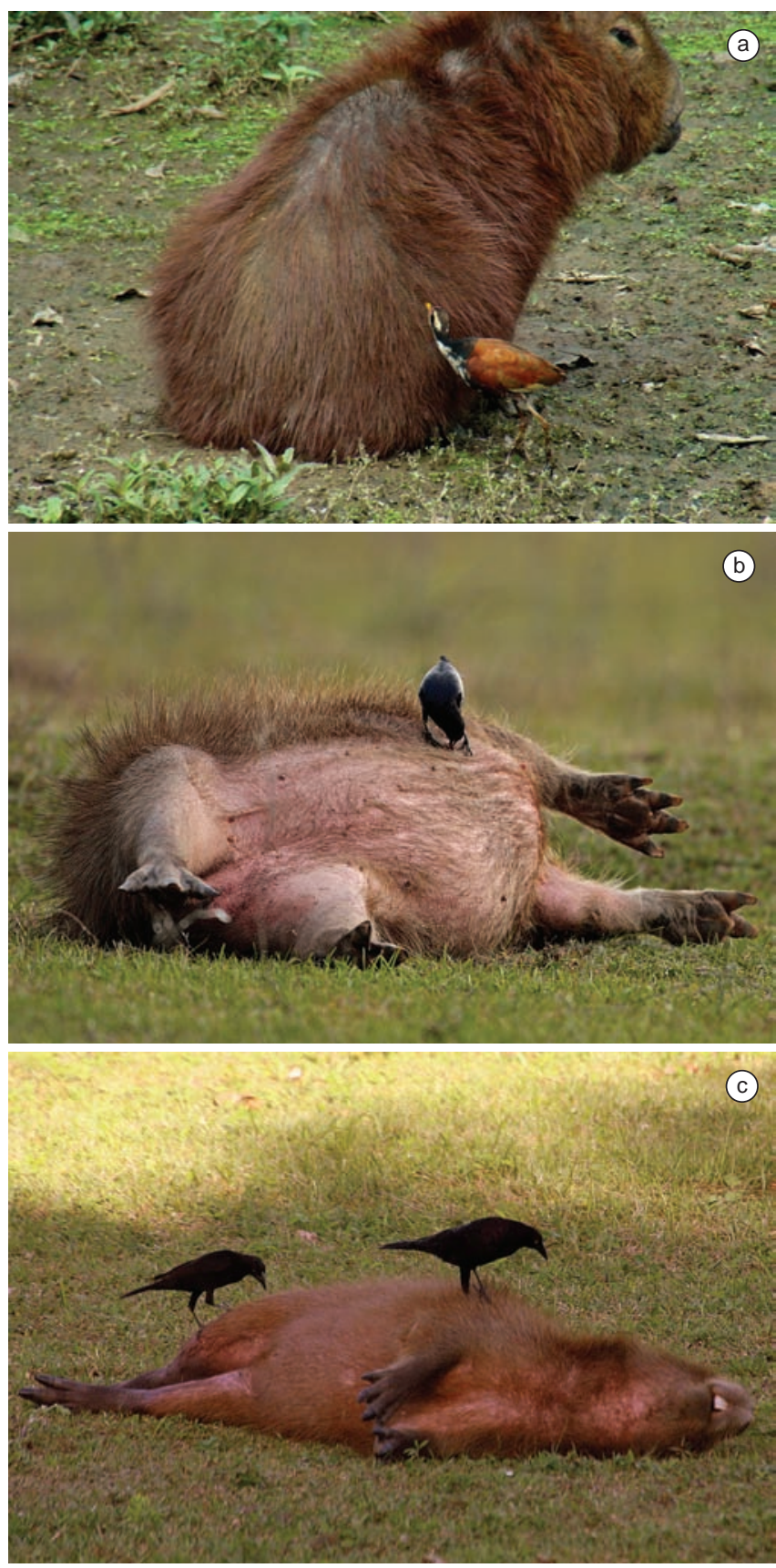

Figure 2. Cleaner birds and their clients: juvenile Wattled Jacana (Jacana jacana) picks arthropods and debris from the rump of a sitting capybara (a); Shiny Cowbird (Molothrus bonariensis) pulls a tick from the belly of a posing capybara (b); Giant Cowbirds (Molothrus oryzivorus) inspect the right side of a posing capybara (c). Photo credits: Horácio de Almeida (a); Darío Podestá (b); Eric Gallardo (c).

Figura 2. Aves limpadoras e seus clientes: jaçanã juvenil (Jacana jacana) cata artrópodes e partículas na anca de uma capivara sentada (a); vira-bosta (Molothrus bonariensis) puxa um carrapato do ventre de uma capivara posando (b); iraúnas-grandes (Molothrus oryzivorus) examinam o lado direito de uma capivara posando (c). Créditos das fotografias: Horácio de Almeida (a); Darío Podestá (b); Eric Gallardo (c). 
ally (Sazima 2007a), and its cleaning role is here expanded to catch horseflies (Tabanidae). Unspecified food is recorded to be gleaned by this tyrannid from the fur of capybaras (MacDonald 1981), and its association with these large rodents is well known, the bird using them as beaters or perches (Tomazzoni et al. 2005).

Shiny Cowbird, Molothrus bonariensis (Gmelin). This open country-dwelling icterid was recorded twice associated with resting capybaras, once near a swamp in the region of Itatiba, and once at a pond bank in the region of Campinas, both localities in south-eastern Brazil. The first record was made in late austral winter (August) in the morning, and the second one in spring (October) in the afternoon. In both instances a small bird group composed of three to four individuals was foraging on the ground near the capybaras, when one of the birds flew and perched on a capybara. The bird inspected the back and the neck of the large rodent, from where it pulled one or two ticks. Only once a capybara did pose for the perched bird, lying on its side and exposing its belly. In this particular instance the bird pulled a large tick from the belly, retreating with its group shortly afterwards. Both instances of the association with capybaras lasted about $1 \mathrm{~min}$. The posture of the lying capybara was similar to that recorded in the region of Iberá, north-eastern Argentina, by D. Podestá (pers. comm.) (Figure 2b). The Shiny Cowbird is recorded to glean insects - but not ticks - from cattle in several parts of its range including Brazil (Sick 1997, Jaramillo \& Burke 1999). Capybaras are a new client type recorded for this cowbird, and the posing behaviour of capybaras while cleaned by small birds is a novelty as well. Additionally, the controversial role of the Shiny Cowbird as a tick-picker (Sazima 2007a) is here cleared and the parasite-picking is substantiated.

Giant Cowbird, Molothrus oryzivorus (Gmelin). This open country-dwelling icterid was recorded associated with a resting male marsh deer, Blastocerus dichotomus (Illiger) in the region of Miranda ( 20 $14^{\circ}$ ' S and 56 $\left.6^{\circ} 23^{\prime} \mathrm{W}\right)$, Mato Grosso do Sul State, south-western Brazil (A. Smith, pers. comm.). The record was made in late austral winter (September) in the afternoon. The bird inspected and picked food (presumably ticks) on the right side, shoulder and neck of the deer (Figure 3b). The duration of the association was not recorded, and the deer retreated after a while. The Giant Cowbird was also recorded associated with posing capybaras in the region of Poconé, Mato Grosso State. The association was recorded in early austral winter (June) in the afternoon (E. Gallardo, pers. comm.). Although the association with capybaras is a well known one for this cowbird (Peres 1996, Sazima 2007a), lying while posing is not mentioned and apparently remained unrecorded until now (Figure 2c). Additionally, the deer is a new client type recorded for this cleaner bird.

Sazima (2007a, 2008) suggests that capybaras remaining apparently oblivious and not posing for Giant Cowbirds and Smooth-billed Anis may be related to the small size of these two latter birds as compared with the Yellow-headed Caracara, Milvago chimachima (Vieillot), to which these rodents pose routinely (Sazima 2007a, b, our pers. obs.). In view of the data we present for the Shiny and Giant Cowbirds, this suggestion does not stand and is here invalidated. However, analysing the literature and the records presented here, some suppositions about the posing behaviour of particular clients in this interaction type may be made. Lying on the side and exposing the belly to be cleaned by birds is a posture reported for capybaras and tapirs only, this behaviour not being recorded for cattle and deer (Peres 1996, Sazima 2007a, our pers. obs.). A partial explanation may be that ticks attached to the ventral parts of the stocky and relatively short-legged capybaras and tapirs would not be easily reached by the cleaner birds otherwise. The report of a jumping Yellow-headed Caracara to reach ticks on the ventral side of a standing ox (Sazima 2007a), and the record of four White-winged Trumpeters (Psophia leucoptera Spix) cleaning the ventral side of a deer while slowly walking along with
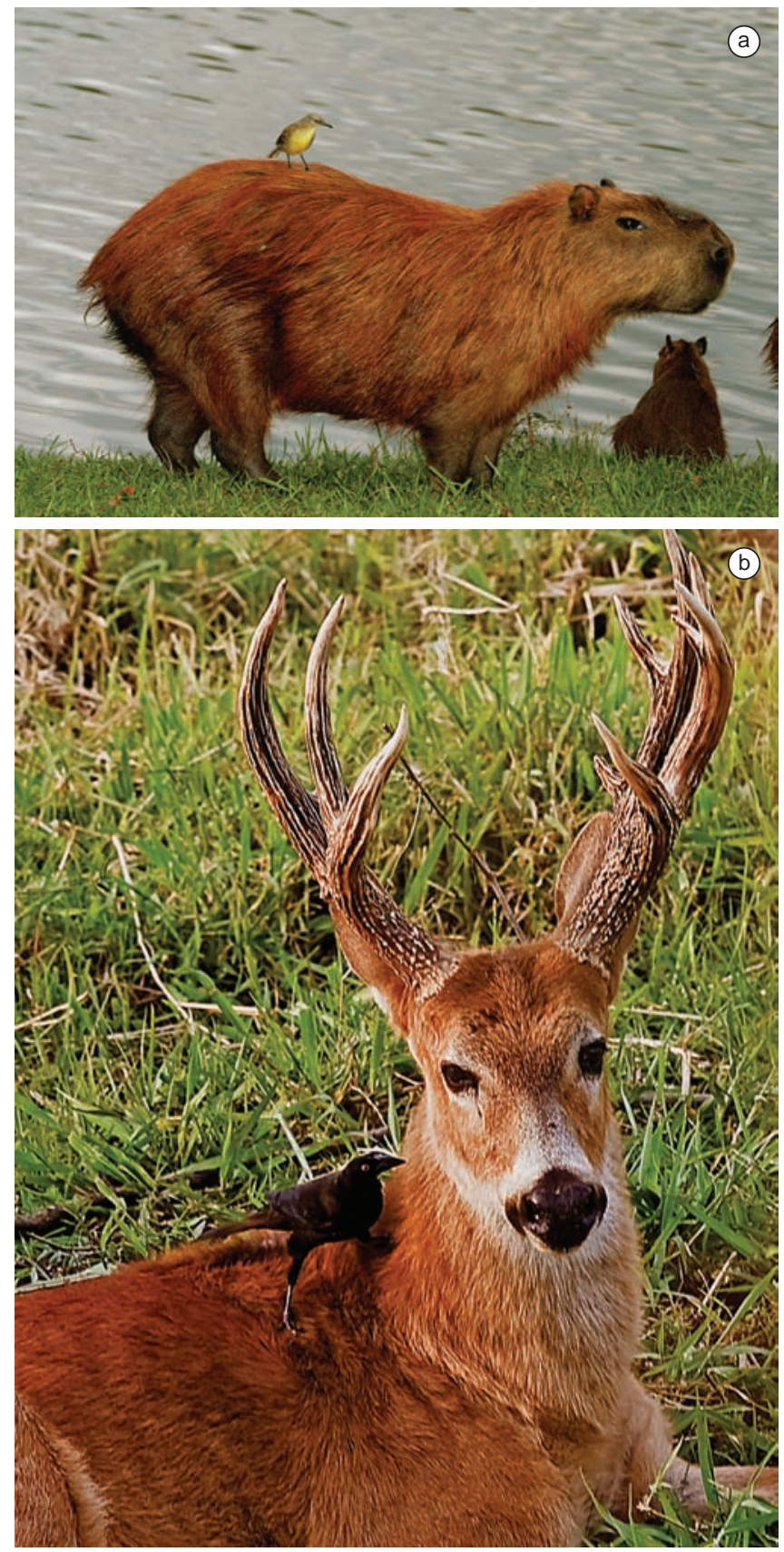

Figure 3. Cleaner birds and their clients: Cattle-tyrant (Machetornis rixosa) watches for horseflies on the back of an alert capybara (a); Giant Cowbird (Molothrus oryzivorus) inspects the neck of a resting marsh deer (b). Photo credits: Ivan Sazima (a); Andy Smith (b).

Figura 3. Aves limpadoras e seus clientes: suiriri-cavaleiro (Machetornis rixosa) espreita mutucas no dorso de uma capivara alerta (a); iraúna-grande (Molothrus oryzivorus) examina o pescoço de um cervo-do-pantanal em descanso. Crédito das fotografias: Ivan Sazima (a); Andy Smith (b).

it (Peres 1996) seem to lend support to our surmise, since both these clients are long-legged as compared with capybaras and tapirs. Thus, at least large cleaner birds are able to reach the ventral side of longlegged clients, such as cattle or deer, without these latter changing their standing or walking postures. On the other hand, both large and small cleaner birds apparently are unable to reach the ventral side of standing capybaras (our pers. obs.); thus, to be rid of ticks attached to the belly and inner hind-thighs these clients have to lie. Another 
explanation may be that while lying on their sides, both the stocky and relatively short-legged capybaras and tapirs react to potential danger standing up very swiftly (as compared with longer-legged herbivores, our pers. obs.), besides running into water or dense bush (Emmons, 1990), and thus possibly may allow for the potential risk to lie while being cleaned.

In the present paper, new clients are recorded for four bird species (Southern Caracara, Black Caracara, Shiny and Giant Cowbirds), the supposed cleaning role of the Wattled Jacana is confirmed, the cleaner role of the Cattle Tyrant is expanded, the tick-picking by the Cattle Egret and the Shiny Cowbird is confirmed, and posing behaviour of capybaras while cleaned by the latter bird species and the Giant Cowbird is apparently recorded for the first time. We note that in the short period of about two years, new and important data were gathered and some of them changed (supported or invalidated) views presented previously, besides adding new insights on the association between cleaner birds and mammals. This strongly indicates that our knowledge of cleaning symbiosis involving bird species that occur in Brazil (and continental Neotropics in general) remains poorly known and that additional field records will likely change the situation further. Additionally, the new data clearly show that the role of amateur ornithologists and professional wildlife photographers in bringing new data to the attention of professional ornithologists and other biologists should always be encouraged.

\section{Acknowledgements}

We thank Horácio de Almeida, Margot K. Castro, Eric Gallardo, Luiz Claudio Marigo, Darío Podestá, Andy Smith, and Gerson Sobreira for sharing with us their essential photographs and records of cleaner birds and their clients; Marlies Sazima for loving support and company in the field; the CNPq and FAPESP for decisive financial support.

\section{References}

BABER, D.W. \& MORRIS, J.G. 1980. Florida scrub jays foraging from feral hogs. Auk 97(2):202.

BELLA, S.D. 2003. Biologia reprodutiva e alimentar de Bubulcus ibis (Linnaeus, 1758) (Ciconiiforme, Ardeidae) e sua ocorrência em Pernambuco, Brasil. Dissertação de Mestrado, Universidade Federal de Pernambuco, Recife, 145 p.

EMMONS, L.H. 1990. Neotropical rainforest mammals: a field guide. University of Chicago Press, Chicago, $281 \mathrm{p}$.

GASSET, J.W., FOLK, T.H., ALEXY, K.J., MILLER, K.V., CHAPMAN, B.R., BOYD, F.L. \& HALL, D.I. 2000. Food habits of Cattle Egrets on St. Croix, U.S. Virgin Islands. Wilson Bull. 112(2):268-271.

GONZALES, J.C. 1995. O controle do carrapato do boi. Edição do Autor, Porto Alegre, $79 \mathrm{p}$.

ISENHART, F.R. \& DeSANTE, D.F. 1985. Observations of scrub jays cleaning ectoparasites from black-tailed deer. Condor 87(1):145-147.
JARAMILLO, A. \& BURKE, P. 1999. New World blackbirds: the icterids. Princeton University Press, Princeton, 432 p.

MACDONALD, D.W. 1981. Feeding associations between capybaras Hydrochoerus hydrochaeris and some bird species. Ibis 123(3):364-366.

MARCUS, M.J. 1985. Feeding associations between capybaras and jacanas: a case of interspecific grooming and possibly mutualism. Ibis 127(2):240-243.

MARTIN, P. \& BATESON, P. 1986. Measuring behaviour, an introductory guide. Cambridge University Press, Cambridge, 200 p.

MASSEI, G. \& GENOW, P.V. 1995. Observations of black-billed magpie (Pica pica) and carrion crow (Corvus corone cornix) grooming wild boars (Sus scrofa). J. Zool. 236(2):338-341.

PERES, C. A. 1996. Ungulate ectoparasite removal by Black Caracaras and Pale-winged Trumpeters in Amazonian forests. Wilson Bull. 108(1):170-175.

SAZIMA, I. 2007a. Unexpected cleaners: Black Vultures (Coragyps atratus) remove debris, ticks, and peck at sores of capybaras (Hydrochoerus hydrochaeris), with an overview of tick-removing birds in Brazil. Rev. Bras. Ornitol. 15(3):417-426.

SAZIMA, I. 2007b. The jack-of-all-trades raptor: versatile foraging and wide trophic role of the Southern Caracara (Caracara plancus) in Brazil, with comments on feeding habits of the Caracarini. Rev. Bras. Ornitol. 15(4):592-597.

SAZIMA, I. 2008. Validated cleaner: the cuculid bird Crotophaga ani picks ticks and pecks at sores of capybaras in southeastern Brazil. Biota Neotrop. 8(1): 213-216. http://www.biotaneotropica.org.br/v8n1/pt/ abstract?article+bn00308012008

SICK, H. 1997. Ornitologia brasileira. Editora Nova Fronteira, Rio de Janeiro, $862 \mathrm{p}$.

SUCKSDORFF, A. 1985. Pantanal, um paraíso perdido? Editora Rio Gráfica, Rio de Janeiro, $160 \mathrm{p}$.

TELFAIR II, R.C. 2006. Cattle Egret (Bubulcus ibis). In The birds of North America (A. Poole, ed.). Cornell Lab of Ornithology, Ithaca. http://bna. birds.cornell.edu/bna/species/113 (last access on 23/10/2009).

TOMAZZONI, A.C., PEDÓ, E. \& HARTZ, S.M. 2005. Feeding associations between capybaras Hydrochoerus hydrochaeris (Linnaeus) (Mammalia, Hydrochaeridae) and birds in the Lami Biological Reserve, Porto Alegre, Rio Grande do Sul, Brazil. Rev. Bras. Zool. 22(3):713-716.

WEEKS, P. 2000. Red-billed oxpeckers: vampires or tickbirds? Behav. Ecol. 11(2):154-160 